DOI: https://doi.org/10.32839/2304-5809/2020-12-88-35

удК 331.215

Слинько О.Ю., Ченцова Ю.П.

Західнодонбаський інститут

Міжрегіональної Академії управління персоналом

\title{
ВИКОРИСТАННЯ МЕТОДУ КЛАСТЕРНОГО АНАЛІЗУ ДЛЯ ДОСЛІДЖЕННЯ РІВНЯ ДИФЕРЕНЦАЦІЇ ДОХОДІВ НАСЕЛЕННЯ ЗА РЕГІОНАМИ
}

\begin{abstract}
Анотація. В умовах системної кризи, в якій перебувае економіка країни, питання боротьби з бідністю, зменшення диференціації доходів населення та підвищення їх середнього рівня виходять на перший план. У статті було здійснене моделювання процесів формування доходів населення в регіонах країни і виявлено, що у структурі доходів населення основну частину складає заробітна плата, регіони $є$ неоднорідними за формуванням доходів. Для ощінки неоднорідності формування доходів населення в регіонах країни було застосовано методи кластерного аналізу, у результаті чого регіони розподілились на три кластери: кластер з високим рівнем заробітної плати, кластер з середнім рівнем заробітної плати, але високим рівнем заборгованості по ії виплаті, кластер з найнижчими показниками рівня оплати праці, але 3 меншою заборгованістю.
\end{abstract}

Ключові слова: доходи населення, заробітна плата, методи, кластерний аналіз, диференціація, індикатор.

Slynko Olga, Chencova Juliya Zahidnodonbaskyy institute of Interregional Academy of Personnel Management

\section{USING THE METHOD OF CLUSTER ANALYSIS TO STUDY THE LEVEL OF DIFFERENTIATION OF POPULATION INCOME BY REGIONS}

Summary. In the terms of the systemic crisis in which the country's economy finds itself, the issues of combating poverty, reducing the differentiation of population income and raising the average level come to the fore. Issues of assessment and analysis of population income are of interest to both representatives of the state administration and representatives of the banking and insurance sectors. At a time when numerous transformations and reforms are being undergone in Ukraine, and crises are observed in almost all sectors of the economy, the problems of analyzing the processes of income generation are very relevant because they reflect the level of its economic security. The results of the analysis have showed that Ukraine lags far behind the average wages in most EU countries and the world. It has been also analyzed that the formation of population income in different regions of the country depends on the state of socio-economic development of the region, the situation on the labor market, the Covid-19 incidence condition in the region and related restrictions, and other political and economic reasons. It has been noted that, in addition to standard methods of statistical data analysis, there is a wide range of more complex and advanced methods of analysis which allow not only to assess the level of research indicators, but also to take into account regional factors and features of their formation. Mathematical tools have been used to identify the reasons for the uneven formation of labor population income in the regions of the country and to study the differentiation of labor incomes, namely - methods of cluster analysis using programming language $R$. As a result of analysis it has been revealed that the main part of the population income structure is wages, the regions are heterogeneous in terms of income generation and are divided into three clusters: the cluster with a high level of wages; the cluster with an average level of wages and GRP, but with a high level of debt; the cluster with the lowest wages, but with less debt. For low-income clusters, it has been recommended to implement anti-crisis and economic growth programs to support entrepreneurship at the state level.

Keywords: population income, wages, methods, cluster analysis, differentiation, indicator.

$\Pi$ остановка проблеми. В умовах системної кризи, в якій перебувае економіка країни, питання боротьби з бідністю, зменшення диференщіації доходів населення та підвищення їх середнього рівня виходять на перший план. Інформація з офріційних статистичних джерел щодо рівня заробітної плати населення за регіонами України демонструе суттеву диференціацію доходів населення, залежно від регіону. Питання оцінки та аналізу доходів населення цікавлять як представників державного апарату управління, так і представників банківської, страхової сфери (оцінка платоспроможності особи та її зміні у часі). У той час, коли в Україні проходять численні перетворення та редорми, а кризові явища спостерігаються майже у всіх секторах економіки, проблеми аналізу процесів формування доходів населення виходять на перший план, оскільки відображують рівень його економічної захищеності.

Аналіз останніх досліджень і публікацій. Питаннями оцінки та аналізу добробуту населення, рівня доходів населення займалися багато закордонних та вітчизняних вчених: Горбатов В., Зінченко В., Герасимчук В., Долишний М., Айвазян В., Лібанова Е., Павловська О., Новак І., Якуненко Н. та інші [2]. Зокрема, такі вчені як Садова У., Семів Л., Ридзак О. проводили регіональні дослідження рівня життя населення. Тому у запропонованій статті увагу зосереджено на застосуванні математичного інструментарію дослідження диференціації трудових доходів населення.

Виділення невирішених раніше частин загальної проблеми. Наявні наукові дослідження, об'єктом яких виступає рівень доходів 
населення або його складові, містять загалом теоретичні засади та стандартні методи статистичного аналізу даних (розрахунок середнього значення, стандартного відхилення, темпів зростання, тощо). Але, на наш погляд, на сьогодні існує широке коло більш складних і досконалих методів аналізу, що дозволяють не тільки ощінити рівень досліджуваних показників, але й врахувати регіональні (територіальні) чинники та особливості їх формування. Тому у запропонованій статті увагу зосереджено на аналізі нерівномірності формування трудових доходів населення в регіонах шляхом застосування математичного інструментарію дослідження диференщіації трудових доходів населення, а саме - методів кластерного аналізу з використанням мови програмування R.

Мета дослідження. Встановлення і аналіз чинників нерівномірності трудових доходів населення у розрізі регіонів.

Виклад основного матеріалу. Оплата праці населення України становить більше половини його доходів (51,6\% у 2019 р., рис. 1). Наступна за розміром стаття грошових доходів населення в Україні - це пенсії, стипендії, соціальні допомоги, що надано готівкою (27,5\%). Грошова допомога від родичів, інших осіб становить біля 7\%, доходи від підприемницької діяльності та самозайнятості становлять $5,1 \%$ від грошових доходів, а доходи від продажу сільськогосподарської продукції, робіт та послуг становлять найменшу частину - $3,1 \%$ доходів.

Оскільки частка оплати праці населення перевищуе 50\% його доходів, то вона є найважливішим чинником його добробуту. Рівень середньої заробітної плати населення за регіонами України у грудні 2019 р. наведено на рис. 2.

Динаміка цього показника з 2017 по 2020 рік у порівнянні з деякими країнами світу наведена на рис. 3.

Результати аналізу показують, що в Україні рівень середньої заробітної плати зростає 3313 дол. у 2017 р. до 428 дол. у 2020 р., і хоча спостерігається позитивна динаміка цього рівня, однак, порівняно з іншими країнами світу, рівень середньої заробітної плати в Україні є дуже низьким. Так, найвищий рівень середньої заро- бітної плати, що становить більше 4 тис.доларів США, був зафіксований у грудні 2019 року у Норвегї (4,761 тис. дол.), Німеччині (4,442 тис. дол.), США (4,1 тис.дол.). Середній рівень заробітної плати близько 3 тис. дол. було зафіксовано у Фінляндії, Ірландії, Франції, Ізраїлі, Канаді та Південній Кореї. Дещо нижчим, ніж в Україні, у 2019 році було зафіксовано рівень середньої заробітної плати у Грузї (420 дол.), Азербайджані (419 дол.), Монголії (416 дол.), Вірменії (397 дол.), Мексиці (380 дол.), Киргизстані (258 дол.) і Таджикистані (139 дол.) [8].

Результати аналізу показали, що Україна суттево відстає за показником рівня середньої заробітної плати від більшості країн ЄС і світу, тому дослідження чинників та особливостей формування даного індикатора добробуту населення є особливо актуальним у складний період трансдормащії економіки країни. Проаналізувавши загальну динаміку рівня реальної заробітної плати з 2014 по 2020 рік (рис. 4), фріксуємо фракт її зростання до 2017 року та зниження у 2018 та 2020 роках.

Формування доходів населення в різних регіонах країни залежить від стану соціально-економічного розвитку регіону, ситуащії на ринку праці, стану захворюваності на Covid-19 у регіоні та відповідно тих обмежень, які з ним пов'язані, тому і спостерігається їх диференціація. Для виявлення причин нерівномірності процесів фрормування трудових доходів населення в регіонах країни застосуемо методи кластерного аналізу на основі таких показників, як: рівень середньомісячної заробітної платні у розрахунку на одного штатного працівника (Wage, грн.), валовий регіональний продукт на одну особу (GRP); заборгованість з заробітної плати станом на початок року (Dept).

$\mathrm{У}$ додатку наведено вихідні дані для кластерного аналізу за 2019 р. [1; 3; 6].

Вибір індикаторів здійснено 3 тих міркувань, що заробітна плата - основне джерело доходів більшості населення країни, тобто цей показник буде характеризувати диференціацію трудових доходів населення за регіонами. Рівень валового регіонального продукту дозволить виявити регіони, що характеризуються більш стабільним економічним
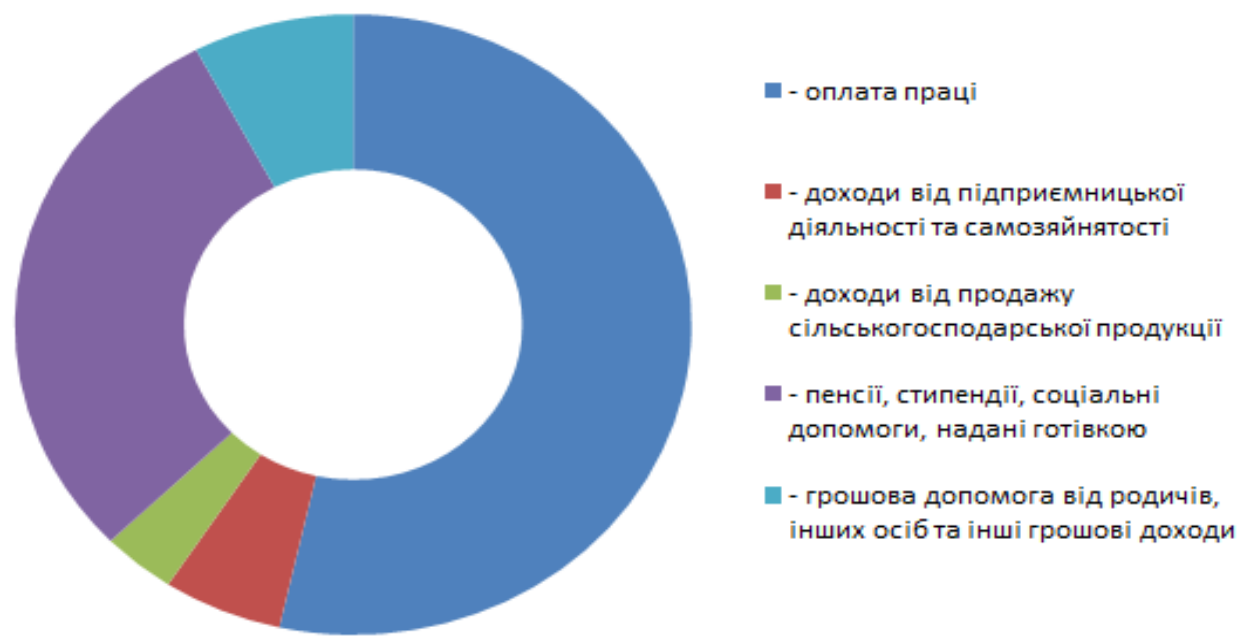

Рис. 1. Структура грошових доходів населення України у 2019 р. 


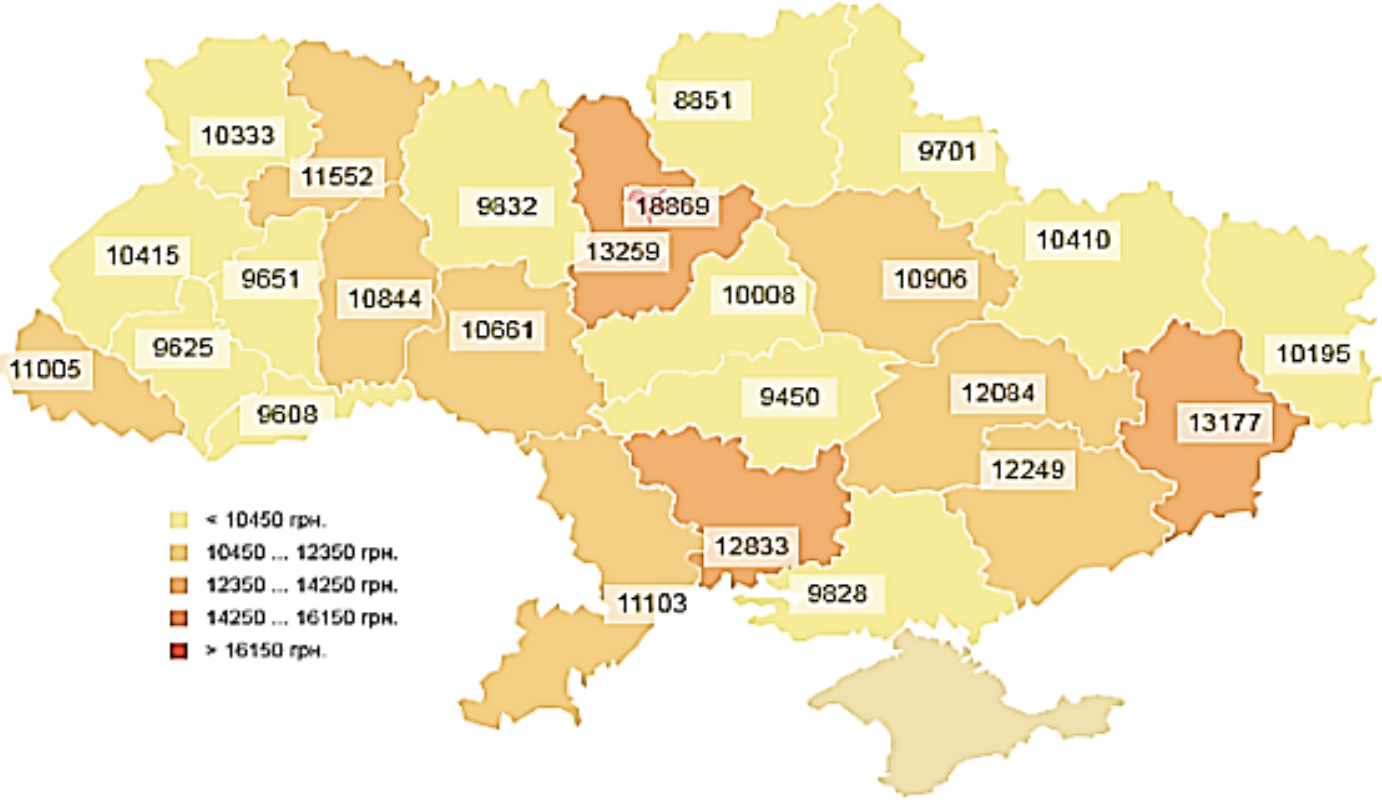

Рис. 2. Рівень середньої заробітної плати населення за регіонами України у грудні 2019 р. Джерело: розроблено авторами за даними [6]

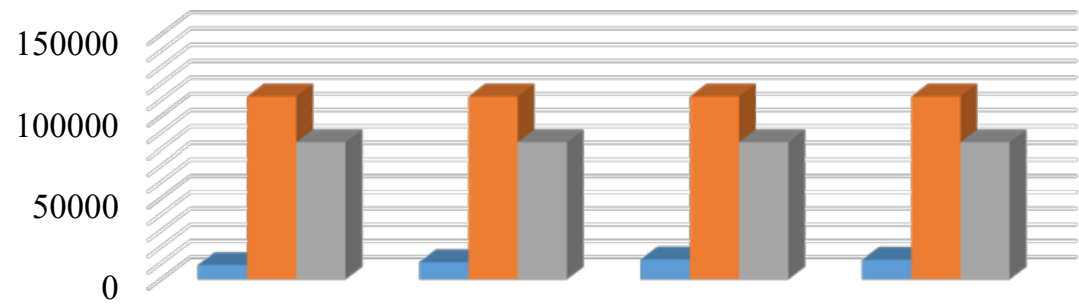

грудень 2017 грудень 2018 грудень 2019 вересень 2020

- Україна

- США, Норвегія, Німеччина

пінляндія, Ірландія, Франція, Ізраїль, Канада та Південна Корея.

Рис. 3. Рівень середньої заробітної плати населення України (в динаміці) у порівнянні з середнім рівнем заробітних плат деяких країн світу, грн.

Джерело: розроблено авторами за даними [7]

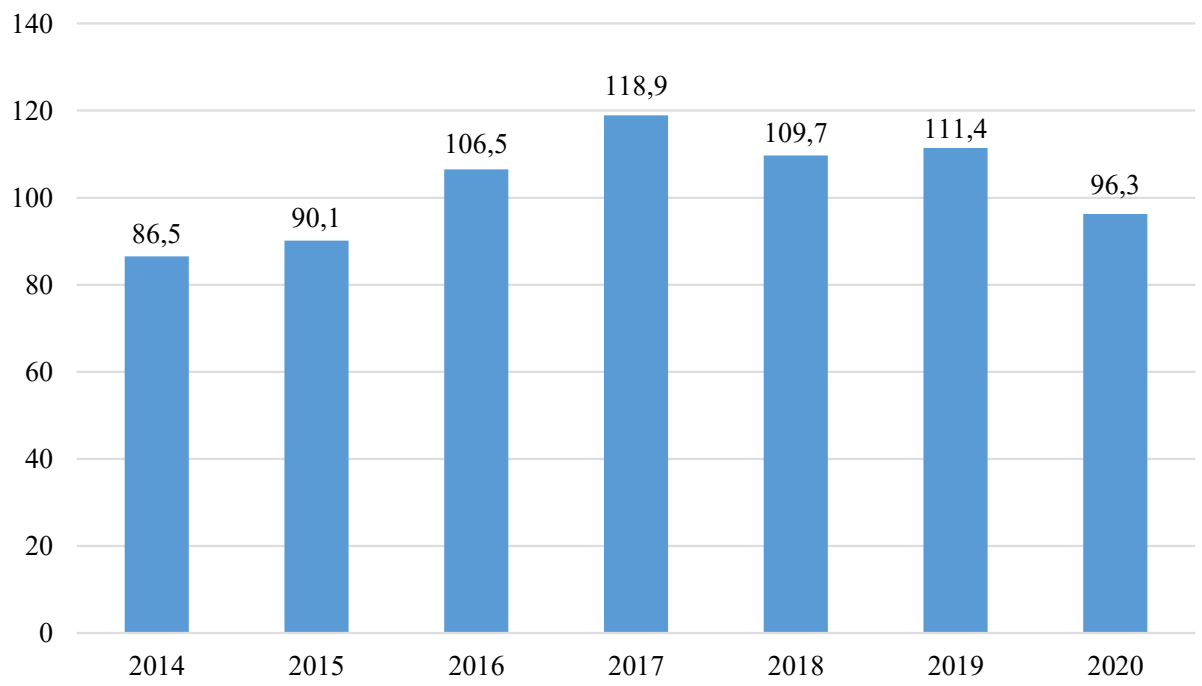

Рис. 4. Темпи зростання реальної заробітної плати населення України, \% 
рівнем, показавши усереднені прогнозні доходи від підприемницької діяльності. Показник заборгованості з заробітної плати свідчить про наявність проблеми 3 виплатою доходів, що призводить до зростання рівня фрінансових ризиків населення.

Для реалізащії методів кластерного аналізу було використано мову програмування $\mathrm{R}$, що додатково слугує обчислювальним середовищем для обробки інформації сучасними статистичними методами [4]. Для визначення кількості кластерів було побудовано графрік каменистого осипу (рис. 5), згин якого вказуе на кількість кластерів, на які потрібно розбити дані. 3 графріку було визначено, що дані слід розбити на три кластери. Для цього було використано метод K-середніх та розраховано координати центрів кластерів (рис. 6).

На рис. 7 зображені візуальні результати кластерного розбиття для трьох кластерів.

Як бачимо, всі кластери розділені досить суттєво. Першій кластер регіонів (фіолетовий колір) - це місто Київ, що має найбільші показники за рівнем заробітної плати та ВРП. Третій кластер регіонів (зелений колір) - мають середні показники рівня заробітної плати та ВРП, але вищий рівень заборгованості за зарплатою. До цього кластеру ввійшли Дніпропетровська, Запорізька, Харківська, Київська, Полтавська області. Другий кластер регіонів (червоний колір) - найгірші за показниками доходів регіони, але з меншою заборгованістю. До цього кластеру ввійшли решта 19 регіонів, але найбільш нетиповий регіон у цьому кластері - Донецька область, що характеризується нетиповим для кластеру високим рівнем заборгованості.

Висновки та перспективи подальших досліджень. Таким чином, було здійснене моделювання процесів формування доходів населення в регіонах країни і виявлено, що у структурі доходів населення основну частину (біля 50\%) складає заробітна плата, регіони є неоднорідними за формуванням доходів та розподілені на три кластери: кластер з високим рівнем заробітної плати (м. Київ); кластер 3 середнім рівнем заробітної плати та ВРП, але високим рівнем заборгованості (Дніпропетровська, Запорізька, Харківська, Київ-

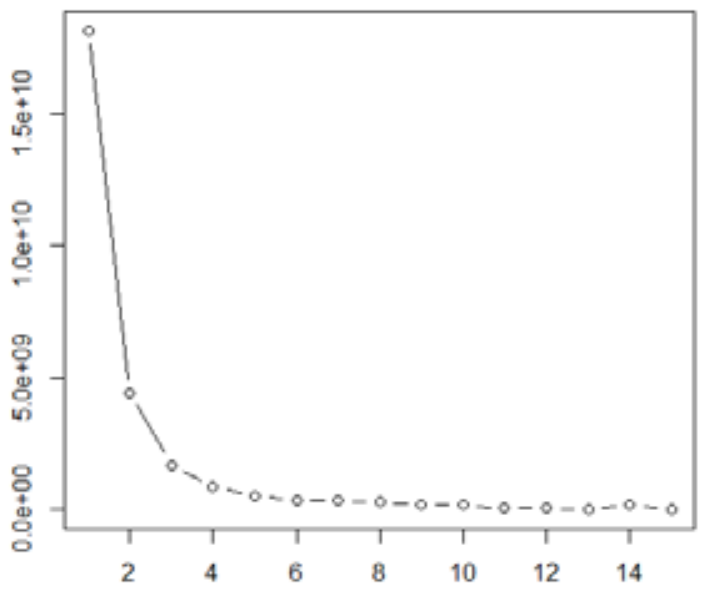

Рис. 5. Графік каменистого осипу

Джерело: розроблено авторами

\begin{tabular}{|c|c|c|c|}
\hline Group & Wage & GRP & Dept \\
\hline 1 & 6732.000 & 155904.00 & 84.200 \\
\hline 2 & 3482.737 & 31721.84 & 42.365 \\
\hline 3 & 4039.800 & 57764.20 & 86.180 \\
\hline
\end{tabular}

Рис. 6. Координати утворених кластерів

Джерело: розроблено авторами

ська, Полтавська області); кластер з найнижчими показниками рівня оплати праці, але 3 меншою заборгованістю. Аналізуючи структуру утворених кластерів, можна зробити висновок, що збільшення доходів населення, а відповідно, зростання купівельної спроможності і споживчого попиту багато в чому залежать від рівня промислового виробництва у регіоні. Тому регіонам 3 низьким рівнем заробітної плати в першу чергу слід застосувати антикризові програми та програми економічного зростання на державному рівні для підтримки підприємництва. У свою чергу, підвищення добробуту населення і зв'язане з ним збільшення платоспроможного попиту будуть сприяти розвитку економіки країни.

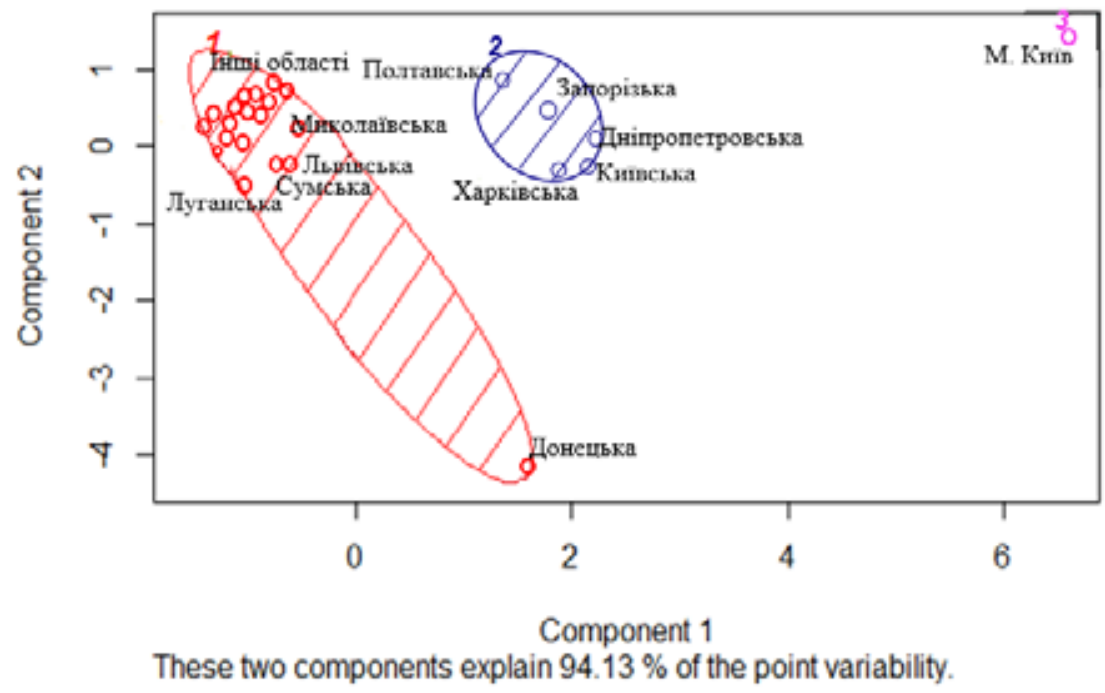

Рис. 7. Результати візуалізації кластерного розбиття для трьох кластерів 


\section{Список літератури:}

1. Валовий регіональний продукт у 2019 році. Державна служба статистики України : Статистичний збірник / за редакцією I.M. Нікітіної. Київ, 2020. 150 c. URL: http://www.ukrstat.gov.ua/ (дата звернення: 01.12.2020).

2. Гончарова С.Ю., Семенченко А.В. Причини і тенденції зміни рівня доходів населення за регіонами України. Науковий вісник Херсонського державного університету. 2015. № 14. Ч. 1. С. 124-127.

3. Експрес-випуск «Заборгованість із виплати заробітної плати» на 1 листопада 2020 року. Державна служба статистики України. URL: http://www.ukrstat.gov.ua/ (дата звернення: 03.12.2020).

4. Кластерный анализ с примерами на R. URL: http://www.algorithmist.ru/2011/05/clustering-with-example-in-r.html

5. Мандель И.Д. Кластерный анализ. Москва : Финансы и статистика, 1988. 176 с.

6. Середня заробітна плата по Україні за останні роки. Міністерство фінансів України. URL: https://index.minfin.com.ua/ ua/labour/salary/average/ukraina/ (дата звернення: 27.11.2020).

7. Середня зарплата в Україні та інших країнах світу. Слово і діло. Аналітичний портал. URL: https://www.slovoidilo.ua/ 2020/05/29/infografika/suspilstvo/serednya-zarplata-ukrayini-ta-inshyx-krayinax-svitu. (дата звернення: 30.11.2020).

8. Список країн Європи за середньою місячною зарплатнею. URL: https://tradingeconomics.com (дата звернення: 28.11.2020).

\section{References:}

1. Nikitina I.M. (ed). (2020) Derzhavna sluzhba statystyky Ukrainy. Valovyj regionalnyj produkt u 2019 roci [Gross regional product in 2019]: Statystychnyj zbirnyk / za redakciyeyu I.M. Nikitinoyi. Kyiv. (accessed 01 December 2020).

2. Goncharova S.Yu., Semenchenko A.V. (2015) Prychyny i tendenciyi zminy rivnya doxodiv naselennya za regionamy Ukrayiny [Reasons and trends in the level of income of the population by regions of Ukraine]. Naukovyj visnyk Khersonskogo derzhavnogo universytetu [Scientific Bulletin of Kherson State University], vol. 14, no. 1, pp. $124-127$.

3. Derzhavna sluzhba statystyky Ukrainy (2020) Express issue "Wage arrears" on November 1, 2020. Kyiv: Informatsiino-analitychne ahentstvo. Available at: http://www.ukrstat.gov.ua/ (accessed 03 December 2019).

4. Klasternyj analyz s prymeramy na R [Cluster analysis with examples on R]. Available at: http://www.algorithmist.ru/ 2011/05/clustering-with-example-in-r.html

5. Mandel Y.D. (1988) Klasternyj analyz [Cluster analysis]. Moscow: Fynansy i statystyka.

6. Ministry of Finance of Ukraine. Serednya zarobitna plata po Ukrayini za ostanni roky [The average salary in Ukraine in recent years]. Available at: https://index.minfin.com.ua/ua/labour/salary/average/ukraina/ (accessed 27 November 2020).

7. Serednya zarplata v Ukrayini ta inshyx krayinax svitu [The average salary in Ukraine and other countries]. Slovo $i$ dilo. Analitychnyj portal [Word and deed. Analytical portal]. Available at: https://www.slovoidilo.ua/2020/05/29/ infografika/suspilstvo/serednya-zarplata-ukrayini-ta-inshyx-krayinax-svitu (accessed 30 November 2020).

8. Spysok krayin Yevropy za serednoyu misyachnoyu zarplatneyu [List of European countries by average monthly salary]. Available at: https://tradingeconomics.com (accessed 28 November 2020).

Додаток

Таблиця 1

Вихідні дані кластерного аналізу, 2019 р.

\begin{tabular}{|c|c|c|c|}
\hline Регioн* & $\begin{array}{c}\text { Середньомісячна заробітна } \\
\text { плата (у розрахунку на одного } \\
\text { штатного працівника, грн.) } \\
\end{array}$ & $\begin{array}{l}\text { ВРП на одну } \\
\text { особу, грн. }\end{array}$ & $\begin{array}{c}\text { Заборгованість з ЗП (станом } \\
\text { на початок року, млн. грн.) }\end{array}$ \\
\hline Вінницька & 10661 & 71104 & 17,842 \\
\hline Волинська & 10333 & 58297 & 58,809 \\
\hline Дніпропетровська & 12084 & 114784 & 396,754 \\
\hline Донецька & 13177 & 45959 & 921,391 \\
\hline Житомирська & 9832 & 62911 & 13,548 \\
\hline Закарпатська & 11005 & 41706 & 5,720 \\
\hline Запорізька & 12249 & 85784 & 130,953 \\
\hline Івано-Франківська & 9625 & 57033 & 32,812 \\
\hline Київська & 13259 & 112521 & 165,671 \\
\hline Кіровоградська & 9450 & 67763 & 17,371 \\
\hline Луганська & 10195 & 16301 & 152,384 \\
\hline Львівська & 10415 & 70173 & 158,602 \\
\hline Миколаївська & 12833 & 70336 & 56,662 \\
\hline Одеська & 11103 & 72738 & 86,676 \\
\hline Полтавська & 10906 & 123763 & 92,911 \\
\hline Рівненська & 11552 & 49044 & 13,809 \\
\hline Сумська & 9701 & 62955 & 345,448 \\
\hline Тернопільська & 9651 & 46833 & 34,922 \\
\hline Харківська & 10410 & 86904 & 582,956 \\
\hline Херсонська & 9828 & 52922 & 50,769 \\
\hline Хмельницька & 10844 & 59583 & 13,417 \\
\hline Черкаська & 10008 & 76904 & 58,149 \\
\hline Чернівецька & 9608 & 37441 & 3,896 \\
\hline Чернігівська & 8851 & 69725 & 18,945 \\
\hline м. Київ & 18869 & 283097 & 361,274 \\
\hline
\end{tabular}

* без урахування окупованих територій (Криму, Севастополя, частини Донбасу)

Джерело: розроблено авторами за даними [1; 3; 6] 